\title{
The influence of lead on concentrates quality produced in KGHM Polska Miedz concentrator plants
}

\author{
Witold Pawlos ${ }^{1, *}$, and Małgorzata Krzemińska ${ }^{1}$ \\ ${ }^{1}$ KGHM Polska Miedź S.A., Oddział Zakłady Wzbogacania Rud, ul. Kopalniana 1, 59-101 Polkowice, Polska
}

\begin{abstract}
The behaviour of lead compounds present in feed of beneficiation process has been discussed. Changeability of copper and lead content in feed during last decades has been described. Galena was pointed as a major source of lead and the beneficiation kinetic of this mineral was presented comparing with other sulphides, including copper sulphides. Significant amount of galena together with its very good concentrating properties crucially effect on quality of concentrates produced in Lubin concentrator plant.
\end{abstract}

\section{Introduction}

One of the most important issue of ore processing in Lubin concentrator plant is occurrence accompanied metals with crucial position of lead. The presence of lead in feed significantly influences on grade and quality produced concentrates. Lead is strictly connected with copper orebody or occurs in adjacent roof rocks formations. It makes selective excavation of copper ore difficult or even impossible. Attempts of elimination of lead during flotation process were also unsuccessful. The gradually increase of lead content in feed and consistently raised lead amounts in concentrates effects on achieved ore processing indexes, what was discussed in this paper.

\section{The lead content in ore}

During last years the increase of lead content with simultaneous decrease of copper amounts in feed is being observed at Lubin concentrator plant. The graph showing these phenomena is presented on Fig. 1 where changeability curves of $\mathrm{Cu}$ and $\mathrm{Pb}$ content in ore in 19992015 are plotted.

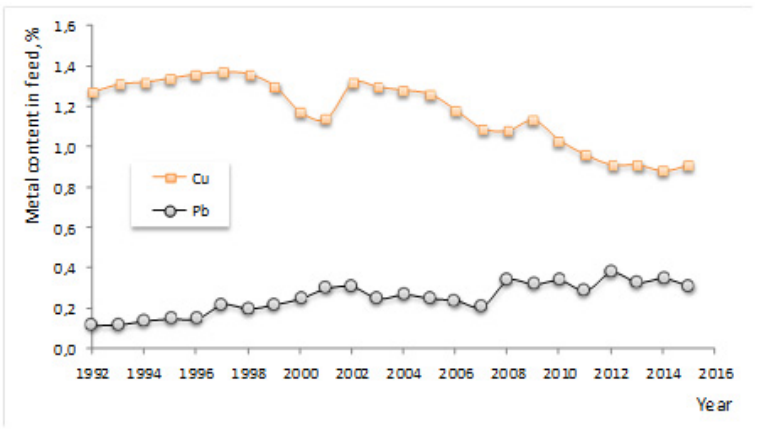

Fig. 1. The changebility of copper and lead in ore processed at Lubin concentrators in 1992-2015 (O/ZWR own materials).
The changes in copper and lead contents observed during last years allow us to make a conclusion that feed to process realized in Lubin concentrator is copper-lead ore (the copper to lead ratio is $2: 1$ ). Lowering the $\mathrm{Cu} ; \mathrm{Pb}$ ratio is the reason of emerging technological issues, especially with achieving the proper quality of final copper concentrates.

In the past many efforts to control the lead content in produced concentrates have been undergone [1]. During flotation research some lead depressors were examined, which are well known and widely used in froth flotation of copper and lead sulphide minerals. Among others the addition starch and dextrines was applied [2-5]. I spite of broad attempts facing the problem of high leads levels in concentrates, no proven solution has been found. Getting higher lead contents effects negatively on concentrate grade at acceptable copper recovery values.

\section{The mineral formations of lead}

In polymetallic copper ore deposit recognised as LegnicaGlogow Copper Basin, lead is present exclusively in a form of galena $(\mathrm{PbS})$, and apart from it there is no other significant lead sources.

Galena creates grains in size from $10 \mu \mathrm{m}$ to some millimetres, mainly in range $30-200 \mu \mathrm{m}$. The grains are dispersed in matrix made of clay-dolomite and carbonates rock formations. Galena can occurs also as aggregates of irregular shapes. In some small amounts, not more than $15-20 \%$ galena is present as associations, mainly with sphalerite, but also with pyrite, chalcopyrite, rarely with bornite [6].

Mineral composition of ore processed in Lubin concentrator plant varied significantly for last decade (Fig. 2). The considerable increase of galena content among other sulphides is noticeable (starting at $2 \%$ level to $20 \%$ of all sulphides) while copper bearing sulphides decrease from $80 \%$ to $50 \%$ of all sulphides. It is confirmed in chemic al assay what is presented on Fig. 1.

\footnotetext{
*Corresponding author: witold.pawlos@kghm.com
} 


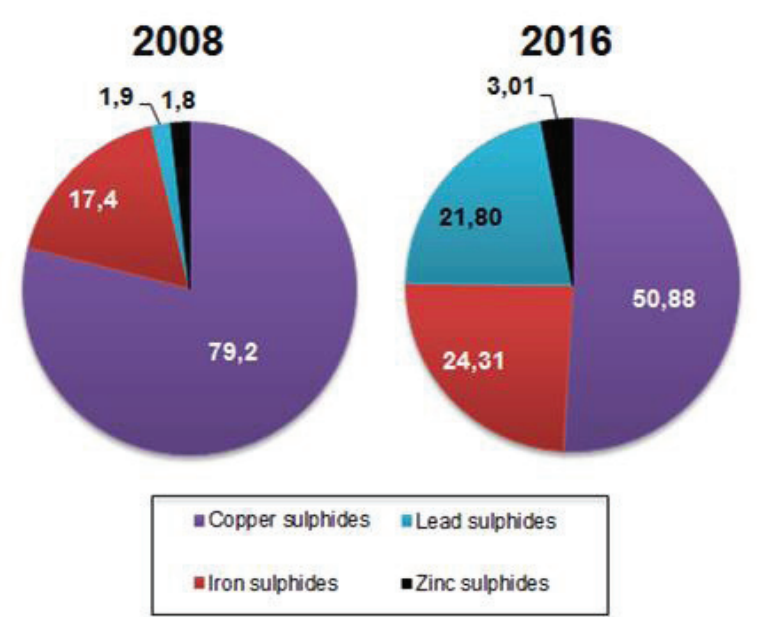

Fig. 2.The mineral composition of feed to Lubin concentrator plant $[7,8]$.

\section{The mineral formations of lead}

During froth flotation process lead has worse upgrading properties than copper [9], see Fig. 3.

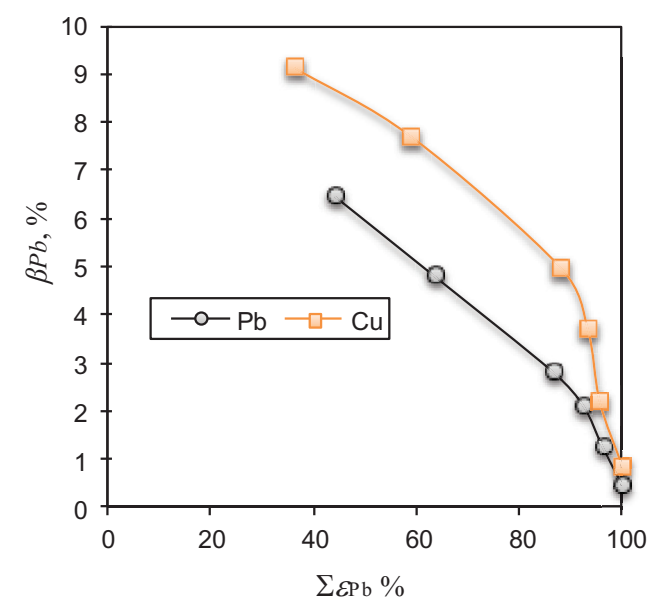

Fig. 3. Halbich upgrading curves for copper and lead at Lubin concentrator plant.

According to bibliography sources [10] galena is classified as a naturally slight hydrophobic mineral and collector-less floating sulphide. Insignificant hydrophobic properties of galena was also confirmed by Drzymala [11] in his research. Some investigations undergone in KGHM Division of Concentrators proved that galena is easily upgraded mineral (see Fig. 4).

High upgrading properties of galena effects elevated amounts lead in concentrates accompanied with high recoveries of this metal during ore beneficiation process realized in Lubin plant. Increasing galena content with simultaneously decreasing content of copper bearing sulphides is responsible for changes in $\mathrm{Cu} / \mathrm{Pb}$ content in ore processed. It affects directly on concentrates grade. Hence the influence of lead present in concentrate on lead content in concentrate in period 2005-2015 is shown on Fig. 5.

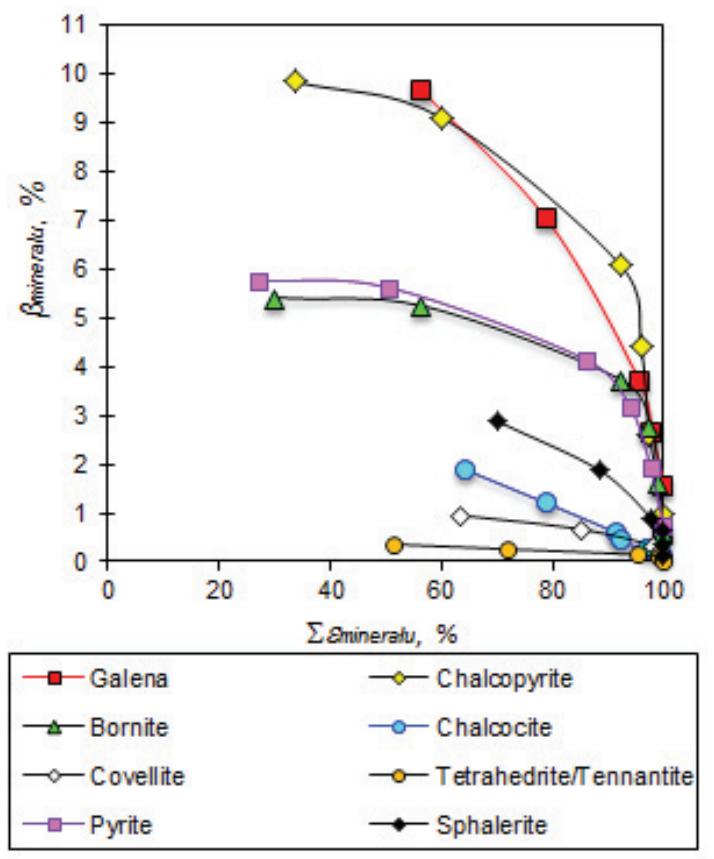

Fig. 4. Halbich upgrading curves for main sulphide minerals present in feed to Lubin concentrator plant.

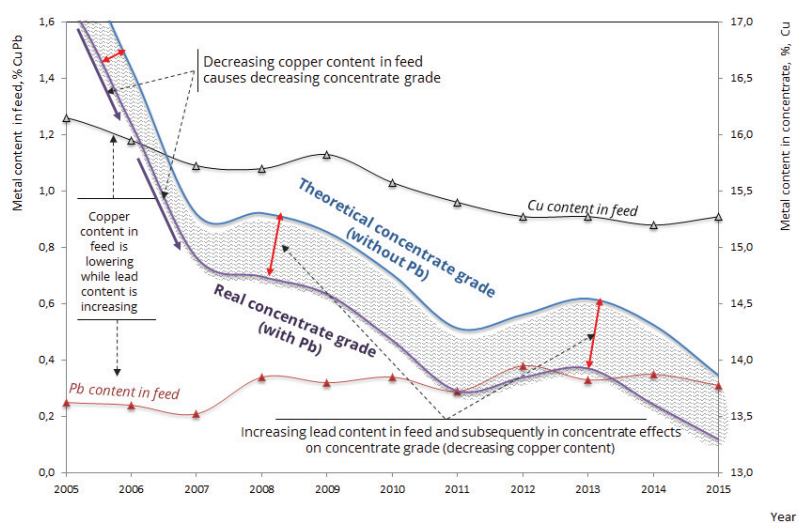

Fig. 4. Influence of $\mathrm{Pb}$ content on concentrate grade in 20052015.

\section{Summary}

The technology applied in KGHM Polska Miedz S.A. Division of Concentrators is based on froth flotation beneficiation process focused on production of bulk concentrates collecting mainly copper, silver and other metals sulphides. The concentrate as the final product of ore processing contains copper but also significant amounts of other components including lead. This is one of the reason of decreasing copper concentrate grade. It is concluded that concentrate produced in Lubin plant is rather copper-lead than "pure copper" concentrate. It should be consider to apply solutions to allow separate copper sulphide apart of other sulphides and waste minerals responsible for decreasing ore beneficiation indexes. However, it must be emphasized that effective lead recovery during pyrometallurgical process in copper 
smelters can provide benefits as it is one of commercial product of KGHM Polska Miedz S.A.

\section{References}

1. R. Bortel, N. Kubacz, Zeszyty Naukowe AGH, Górnictwo z. 132, (1987)

2. A.M. Gaudin A.M.: Flotacja. (Wydawnictwo Śląsk, Katowice, 1963)

3. Lin K.F., Budrick C., L.: Polymeric Depressants. Reagents in Mineral Technology, (1988)

4. Q. Liu, J.S. Laskowski, Int. J. Miner. Process. 27, (1989)

5. A.V. Lopez, A.A. Sanchez, S. Song, H.A. Martinez Garcia, Canadian J. Metall. Mater. Sci. vol. 46, (2003)

6. P. Kijewski, Physicochem. Probl. Miner. Process., 20, 89-96 (1988)

7. K. Trybalski, A. Łuszczkiewicz, J. Drzymała, T. Tumidajski, D. Foszcz, A. Muszer, T. Niedoba, T. Henc, Określenie wplywu wzbogacalności przerabianych rud na jakość koncentratów miedziowych dla potrzeb optymalizacji górniczohutniczego procesu wytwarzania miedzi, Etap II:
Badania wzbogacalności urobku planowanego do wydobycia, Akademia Górniczo-Hutnicza, (raport z badań), Kraków (2008)

8. A. Łuszczkiewicz, M. Duchnowska, A. Bakalarz, A. Muszer, J. Drzymała, M. Komorowska, Ocena $i$ charakterystyka krajowych rud miedzi, produktów $i$ pótproduktów obecnych i badanych technologii pod katem innowacyjnych rozwiąań technologicznych ich wzbogacania, Raport nr W-6/S-010/2016. (2016)

9. A. Łuszczkiewicz, D. Foszcz, J. Drzymała, M. Duchnowska, A. Bakalarz, D. Szyszka, T. Tumidajski, Ż. Konopacka, T. Niedoba, P.B. Kowalczuk, J. Hupka, M. Niewiadomski, P. Karwowski, K. Księżniak, A. Rogala, Opracowanie metodyki badania odczynników flotacyjnych pod katem ich własności użytkowych, Raport Instytutu Górnictwa Politechniki Wrocławskiej, nr I-11/2013/S-30, Wrocław (2013)

10. G.W. Heyes, W.J. Trahar, Int. J. Miner. Process. 4, 317-344 (1977)

11. J. Drzymała, Podstawy mineralurgii, (Oficyna Wydawnicza Politechniki Wrocławskiej, Wrocław, 2001) 